\title{
'The writings of querulous women': contraception, conscience and clerical authority in 1960s Britain
}

\author{
Alana Harris* \\ Department of History, King's College London, Strand, London, WC2R 2LS, \\ UK. Email: alana.harris@kcl.ac.uk
}

On 31 May 1964, Dr Anne Bieżanek travelled from Wallasey to Westminster Cathedral to attend Mass and receive Holy Communion. She was flanked by hoards of reporters, who over the previous six months had fueled extensive media coverage of her establishment of one of the first Catholic birth control clinics in the world, alongside her intertwined personal story of the physical and emotional strain caused by ten pregnancies. Repeatedly refused the sacraments by her local parish priest in consequence of these activities, and unable to gain satisfaction from the Bishop of Shrewsbury, Dr Bieżanek wrote to the Archbishop of Westminster to announce her intention to 'resolve the issue' through an ethical adjudication at the Communion rails.

As the first sustained exploration of this exceptional woman and her sensational life story, this article examines Dr Bieżanek's private correspondence and public persona to illustrate the ways in which her idiosyncratic re-negotiation of spiritual and sexual politics was path breaking in articulating a 'modern' Catholic approach to love and sex and in anticipating the cacophony of such voices elicited by the Humanae Vitae encyclical in 1968. As such, it illustrates the form and force of contrasting and modulating Catholic discourses about love, marriage, and contraception in the post-war period and demonstrates the continuing and critical interplay of religion, infused with the insights of sexology and psychology, when negotiating the sexual and spiritual revolutions of the sixties.

Keywords: Anne Bieżanek, Mariology, birth control, contraception, sex, the Pill

* Earlier versions of this article were presented to the Modern British History seminar (University of Oxford), the Modern Religious History seminar (Institute of Historical Research) and at the 2015 Social History Society conference. The author would like to thank all participants in these forums for their illuminating questions and helpful suggestions. Grateful thanks for encouragement of the research at an early stage are extended to the late Dr Anne Bieżanek and her family thereafter, as well as Rev Dr Peter Phillips, Diocese of Shrewsbury archivist, who could not have been more supportive of my enquiries and for permission to quote from the archive. Thanks are also due to two anonymous reviewers and to Sam Brewitt-Taylor, William Whyte, Timothy Folkard and Lucy Delap for their comments on this essay. The photographs of Dr Bieżanek are published with permission of Getty Images and financial assistance from the late Miss Isobel Thornley's Bequest to the University of London. 
On 29 November 1963, the Daily Mail carried a headline: 'Church Defied. RC Woman Doctor Sets Up Family Planning Clinic'. ${ }^{1}$ The article continued:

tall, auburn-haired, and the mother of seven young children, the 36-year old doctor said: ..."I am taking a stand on something we Catholics cannot sidestep any longer".

Dr Anne Bieżanek's decision to open one of the first Catholic birth control clinics in the world in the front room of her home surgery in Wallasey, Merseyside, would continue to be headline news here, ${ }^{3}$ and in the United States, ${ }^{4}$ for the next twelve months (figure 1).

Alongside this pioneering initiative, which she deemed a 'Christian aid programme', ${ }^{5}$ Dr Bieżanek published a strident, 150-page justification of her actions and their implications. With international distribution through Pan books, ${ }^{6}$ and Harper and Row in the US - while banned in Ireland ${ }^{7}$-it was entitled All Things New: The Declaration of Faith, referencing the eschatological, indeed apocalyptic promises of the Book of Revelation. In the appendix to the book, Dr Bieżanek printed anonymous extracts from some of the thousands of letters she had received from all over the world and one such read:

I hope I will live to see the day when a Higher Domestic Science paper will have a question on the role played by $\mathrm{Dr}$ Anne Bieżanek in liberalising the RC Church to birth control [and] its effects on raising the status of women and on family life in the latter half of the $20^{\text {th }}$ century. ${ }^{8}$

This non-Catholic female correspondent would be disappointed, perhaps, that this article constitutes the first extended treatment of Dr Bieżanek's writings and work, and the part they played in anticipating broader debates about sexuality and contraceptive

\footnotetext{
1 Daily Mail, 29 November 1963, 7.

2 Ibid.
}

3 For example, The Times, 13 January 1964, 5; Catholic Herald, 17 January 1964, 4; Paul Johnson, 'Catholics and Birth Control', New Statesman, 17 January 1964, 72-4; Daily Mail, 23 January 1963, 9; Wallasey News, 15 February 1964, 1; Terence Smith, 'R. C. Birth Control Doctor is to Challenge Archbishop', Sunday Express, 31 May 1964, 7; Daily Mirror, 1 June 1964, 3; The Guardian, 1 June 1964, 4; Daily Telegraph and Morning Post, 1 June 1964, 13 and Monica Furlong, 'One woman ... Eleven Pregnancies that Could Change Society', Daily Mail, 24 November 1964, 8.

4 'British Catholic Backs Birth Curb', New York Times, 21 May 1964, 12 and the review of All Things New, The New York Times, 21 March 1965, 14 (Book Review section).

5 Anne Bieżanek, All Things New: The Declaration of Faith (London: Pan Books, 1964), 59.

6 The original hardcopy of All Things New was published by Peter Smith, and then copyright was transferred to Pan Books, who published it in paperback on 19 February 1965 , priced at $3 / 6 \mathrm{~d}$ with a print run of 100,000 copies. Information provided in an email communication, dated 6 March 2015, from Alyson Sanders, Archivist, Macmillan Publishers.

7 'Eire Bans Book on Contraception', Daily Mail, 18 December 1964, 14.

8 Bieżanek, All Things New, 162. 


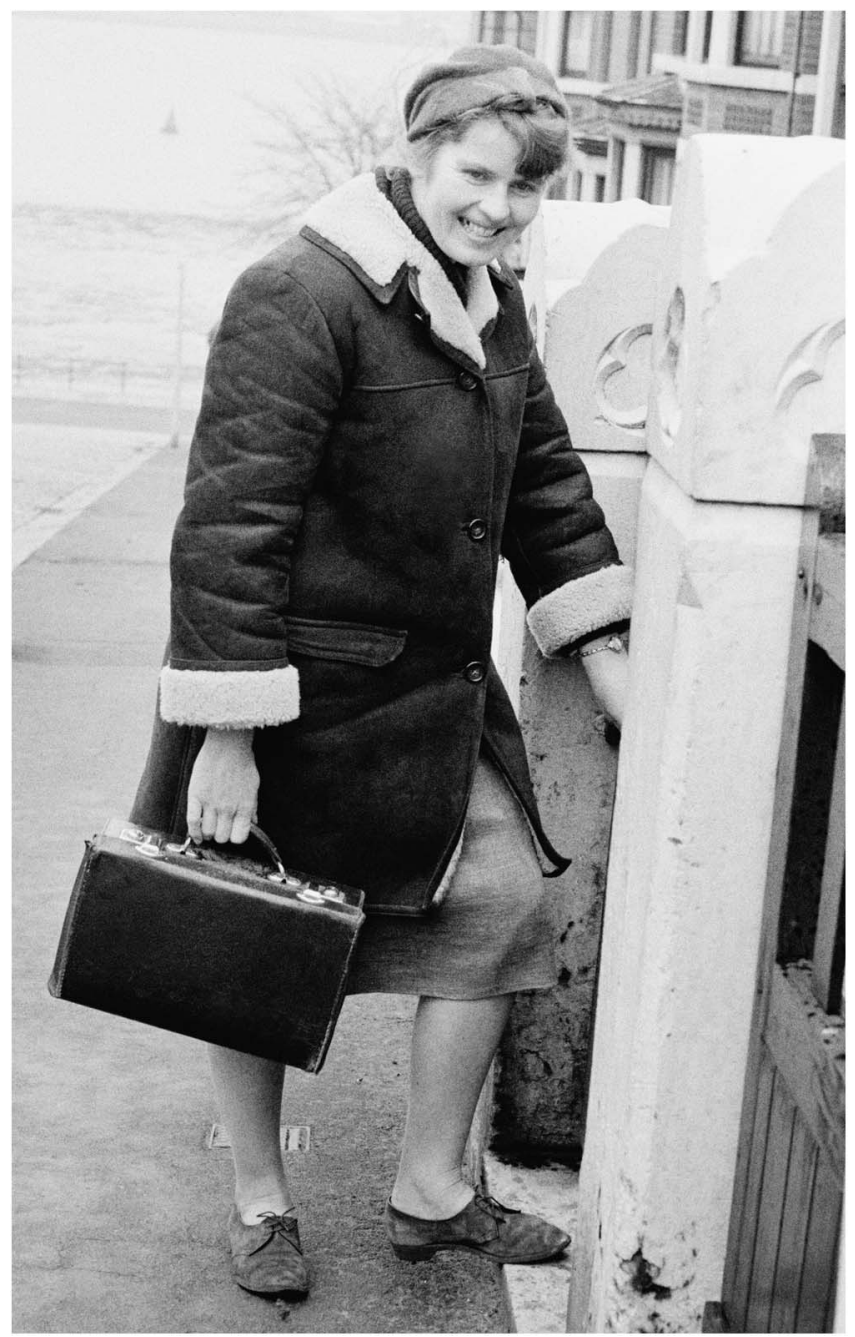

Figure 1. Dr Anne Bieżanek at the front gate of her home surgery, medical bag in hand. Note that this photo, and figure 2 were taken by the well-known 'paparazzi', Ray Bellisario. Permission granted by Getty Images.

cultures in late twentieth century Britain. Yet in the English Catholic Church of the early 1960s, Dr Bieżanek's transgressive writings and provocative actions made her notorious, and clerical commentators disparaged or hailed the force of her intervention within increasingly controversial debates about birth control and the 'primary ends' of marriage. For example Father Alban Byron SJ, writing in the Catholic Missionary Society's journal, the Catholic Gazette, violently disagreed with almost all of Dr Bieżanek's contentions but was forced to acknowledge, euphemistically, that All Things New is the most 
extraordinary marriage book I have ever read. ${ }^{9}$ Much more positively, Canon Harold Drinkwater, a respected catechist and popular author in his own right, ${ }^{10}$ praised the book for eschewing:

all those tactful euphemisms and soft-peddling, those delicate nuances and innuendos, those discreet circumlocutions, which so often oil the chariot wheels of truth and which those of us who write under constant censorship get so good at. ${ }^{11}$

\section{Writing a few months later in Search, he went further in claiming:}

Let nobody imagine for a moment that the author is some kind of nagging eccentric or notoriety-seeker ... Here is a book in the same category as Newman's Apologia. ... an agonia, on the mind of the Church of today, as it re-enacted itself in one lonely human soul. ${ }^{12}$

As this article will explore, nor was there consensus amongst contemporary Catholic laity or clergy about Dr Bieżanek's forthright articulation of the issues. Prompted to write to the Bishop of Shrewsbury by Dr Bieżanek's public actions and the publication of All Things New, Father Joseph Howe of St Ann's Cheadle deplored the "'open forum" of today, in which no longer were the secret and sacred things reserved for God alone'. ${ }^{13}$ In fact, he attributed the catastrophic degeneration of moral standards to such public commentary, which he castigated as the writings of 'querulous women [which] offend against taste'. ${ }^{14}$

The increasingly frequent, indeed insistent written interventions made by Catholic women, and some men, ${ }^{15}$ writing about 'married love' and birth control in the period after the Second World War is only now beginning to receive academic treatment in

9 Alban Byron SJ, 'A Sad Story: Dr Biezanek's Fight against the Church', Catholic Gazette $56,1(1965), 8-9$.

${ }_{10}$ Kester Aspden, 'Drinkwater, Francis Harold (1886-1982)' in Oxford Dictionary of National Biography, eds. Brian Harrison and Lawrence Goldman (Oxford: Oxford University Press, 2004).

11 F. H. Drinkwater, 'The Problem of Contraception', Clergy Review, February 1965: $166-8,167$.

${ }^{12}$ F. H. D. 'Book of the Month', Search: Michael de la Bedoyere's Independent Christian Newsletter, (January, 1965): 346-348, 348.

13 Letter of Father Joseph Howe to Bishop Graser, 10 February 1966, Bishop Graser series (GRAS), file: Mrs Biezanek 1963-72 (AB), Diocese of Shrewsbury Archives (SDA), Woodchurch, Birkenhead.

${ }_{14}^{14}$ Ibid.

15 John Ryan, Family Limitation. Modern Medical Observations on the Use of the "Safe Period" (London: Sheed and Ward, 1955) and Alan Keenan and John Ryan, Marriage: A Medical and Sacramental Study (London: Sheed and Ward, 1955). For information about John Ryan's role (for a time) as the consultant gynaecology to the Catholic Marriage Advisory Council, see Alana Harris, 'Love Divine and Love Sublime: The Catholic Marriage Advisory Council, the Marriage Guidance Movement and the State', in Alana Harris and Tim Jones, eds. Love and Romance in Britain, 1918-1970 (London: Palgrave Macmillan), 188-224. 
a British context. ${ }^{16}$ More scholarly research has been undertaken within an American Catholic historiography considering, for example, the pioneering feminist efforts of Margaret Sanger through to Dr John Rock's explosive bestseller The Time Has Come (1963). ${ }^{17}$ Leslie Woodcock Tentler's consummate explorations of shifting attitudes to and the adoption of contraception by American Catholic men and women have paved the way for comparable studies in other AngloEuropean contexts. ${ }^{18}$ This article takes up this emerging agenda within an English Catholic landscape, and seeks to excavate the theological and practical contributions of one British woman to a wholesale rethinking of the relationship between conscience and clerical authority in the years surrounding the Second Vatican Council. ${ }^{19}$ As it illustrates, the birth control debates and the emergence of new contraceptive technologies were lightening rods for these broader social and theological issues. ${ }^{20}$ As a case study, perhaps, of a 'Catholic Marie Stopes', it forms part of a larger, on-going project examining shifting discourses about love, marriage, sexual knowledge and contraceptive practices, and seeks to integrate the experiences of British Catholic laity and clergy so as to interrogate broader assumptions about chronology, agency and secularity charted by historians of gender and sexuality. ${ }^{21}$

16 Alana Harris, 'Love Divine and Love Sublime'; David Geiringer, 'Catholicism and the Sexual Self: Exploring the Sexual Experiences of Catholic Women in Post-war Britain' (PhD Thesis, University of Sussex, 2015). For an excellent general anthology of British women's writings on love, marriage and sex, see Lesley Hall, Outspoken Women: An Anthology of Women's Writing on Sex, 1870-1969 (London: Routledge, 2005).

17 Loretta McLaughlin, The Pill, John Rock, and the Church: the Biography of a Revolution. (Boston: Little, Brown and Company, 1982), 146-92.

18 Leslie Woodcock Tentler, Catholics and Contraception: An American History (Ithaca: Cornell University Press, 2004); Leslie Woodcock Tentler, ed., The Church Confronts Modernity: Catholicism in the United States, Ireland and Quebec (Washington: Catholic University Press, 2007); Leslie Woodcock Tentler, 'Sex and Subculture: American Catholicism since 1945' in Nancy Christie and Michael Gauverau, eds. The Sixties and Beyond: Dechristianisation in North America and Western Europe, 1945-2000 (Toronto: University of Toronto, 2013), 157-85. See also Michael Gauverau, 'The Emergence of Personalist Feminism: Catholicism and the Marriage-Preparation Movement in Quebec 1940-1966', in Nancy Christie (ed.), Households of Faith: Family, Gender and Community in Canada, 1760-1969 (Montreal: McGill-Queens University Press, 2002), 319-47 and Dagmar Herzog, 'Syncopated Sex: Transforming European Sexual Cultures', American Historical Review 114,5 (2009):1287-1308.

19 Jay P. Corrin, Catholic Progressives in England after Vatican II (Notre Dame Ind: University of Notre Dame Press, 2013); Alana Harris, Faith in the Family: A Lived Religious History of the Second Vatican Council, 1945-82 (Manchester: Manchester University Press, 2013). See also Kathleen Cummings, Tim Matovina and Robert Orsi, eds. A Lived History of the Second Vatican Council (Cambridge: Cambridge University Press, forthcoming).

${ }^{20}$ Hera Cook, 'The English Sexual Revolution: Technology and Social Change', History Workshop Journal 59(1)(2005): 109-128. See, for example Edward Stourton, who described the Humanae Vitae encyclical as 'a watershed with implications that went well beyond biology', Absolute Truth: The Catholic Church in the World Today (London: Viking, 1998), xxiv.

21 Jeffrey Weeks, Sex, Politics and Society: The Regulation of Sexuality since 1800 (London: Longman, 1981); Leslie Hall, Sex, Gender and Social Change in Britain since 1880 (2 $2^{\text {nd }}$ ed., London: Palgrave Macmillan, 2012); Kate Fisher, Birth Control, Sex and Marriage in Britain, 1918-1960 (Oxford: Oxford University Press, 2006); Stephen Brooke, Sexual 
Building upon the insights of Callum Brown on the centrality of gender and biography in interpreting the religious changes of the sixties, ${ }^{22}$ though coming to quite different conclusions about the timing and effects of these radical re-drawings of morality and theology, it seeks to evaluate the ways in which Dr Bieżanek - who presented herself as an ordinary, working-class Catholic 'everywoman'-negotiated this shifting social, moral and religious terrain. It also draws upon recent revisionist work exploring the formative role played by religious discourses alongside, or in contrast to the secular social sciences in the publications of intellectuals and experts attempting to reformulate love, marriage and sex within a 'modern' age. ${ }^{23}$ Using the writings and public activities of one 'querulous' woman to prize open broader debates about birth control well before the Humanae Vitae debacle in 1968, it makes an innovative intervention through demonstrating the contribution Catholicism made in the movement from puritanical reticence to public candour in post-war British sexual cultures. ${ }^{24}$ It is argued that Dr Bieżanek's private correspondence and public persona illustrate the ways in which the boundaries between the public and private, and spiritual and sexual politics were being increasingly re-negotiated by many Catholics through the 1950s and early 1960s. Understandings of the dictates of conscience, intimately intertwined with class, gender and the weakening societal premium placed upon deference and obedience to authority (represented by her husband, priest, Bishop and ultimately the Pope), are key motifs of Dr Bieżanek's exceptional and sensational life story.

\section{Behold the woman: Anne Bieżanek's biography and her theology}

When I interviewed Anne Bieżanek in her home in Wallasey, just a month before her death on 30 November 2010, she opened our

Politics: Sexuality, Family Planning and the British Left from the 1880s to the Present Day (Oxford: Oxford University Press, 2011) and Claire Langhamer, The English in Love: An Intimate History of an Emotional Revolution (Oxford: Oxford University Press, 2013).

22 Callum Brown, The Death of Christian Britain: Understanding Secularisation 1800-2000 (London: Routledge, 2001), 220-8 and 'Secularisation, the Growth and Militancy of the Spiritual Revolution: Religious Change and Gender Power in Britain 1901-2001', Historical Research 80 (2007): 393-418.

23 E.g. Sue Morgan, "Wild Oats or Acorns?" Social Purity, Sexual Politics and the Response of the Late-Victorian Church', Journal of Religious History 31, 2 (2007):151-68; Harry Cocks, 'Religion and Spirituality' in Matt Houlbrook and Harry Cocks, eds. The Modern History of Sexuality (London: Palgrave, 2006), 157-79 and Marcus Collins, ed., The Permissive Society and Its Enemies: Sixties British Culture (London: Rivers Oram Press, 2007).

24 Ross McKibbin, Classes and Cultures: England 1918-51 (Oxford: Oxford University Press, 1998), 296-7, 330; Hera Cook, The Long Sexual Revolution: English Women, Sex and Contraception, 1800-1975 (Oxford: Oxford University Press, 2004); Matthew Grimley, 'The Religion of Englishness: Puritanism, Providentialism and "National Character", 1918-1945', Journal of British Studies, 46, 4 (2007): 884-906; Adrian Bingham, Family Newspapers? Sex, Private Life and the British Popular Press (Oxford: Oxford University Press, 2009). 
conversation with a startling reference to Charles de Gaulle. In response to my querying her conversion to Catholicism in her late teens and the way she 'crossed swords' (as she put it) with the English Catholic Hierarchy, she responded:

I read something that was written about General de Gaulle-[that] he had a precocious sense of destiny. I said "oh yeah, that's me, I have a precocious sense of destiny". And, I sort of bored ahead, I was going to, I [don't] know, I was going to be canonised or bust. Really serious stuff. ${ }^{25}$

A cerebral intensity indeed characterized most of Dr Bieżanek's life. Raised in a Quaker/Anglican household and educated at the progressive Dartington Hall School (and then Dollar Academy when her family moved to Scotland), her father, Ben Greene, was a British Labour Party politician and pacifist interned during World War II on account of his fascist associations. ${ }^{26}$ Describing visits to her father in Brixton where he was imprisoned before his landmark civil liberties trial in 1941, Dr Bieżanek foregrounded his conscientious objection and self-consciously drew inspiration from this parental legacy ${ }^{27}$ rather than the more illustrious careers of his cousins - author Graham Greene and former Director-General of the BBC, Hugh Carleton Greene. Critiquing Jeremy Lewis' 2010 collective biography of the family, ${ }^{28}$ which she characterized as 'a huge book, all about these wretched Greenes', she loyally objected:

I don't think [he] does [my father] justice. I think he gives far too much space to Graham, who I've never had any use for. He's not, I mean, what's so great about Graham? I mean his novels were, I don't know why people are so awed by him! Can't see anything in his novels at all. ${ }^{29}$

When I expressed surprise that she did not esteem what are often thought of as 'quintessentially Catholic' novels, pivoting on themes of sin, guilt and a tortured conscience, ${ }^{30}$ it is to Graham's fictionalization of his relationship with his wife that she turned. As Dr Bieżanek characterized the novelist: he was 'an absolute fraud' in portraying himself as 'some poor Catholic whose wife won't divorce him' when she

25 Author, Interview with Dr Anne Bieżanek, 29 October 2010 ('Cluny', Manor Road, Wallasey CH45 7RG). 2 (hereafter Interview). Informed consent obtained and ethics clearance received through the University of Oxford Central University Research Ethics Committee (CUREC1/08-127). Digital MP3 file and transcript in author's (and Bieżanek family's) possession.

26 A. W. Brian Simpson, In the Highest Degree Odious: Detention without Trial in Wartime Britain (Oxford: Clarendon Press, 1992), 340-52, 356-75.

27 See also preface to All Things New.

28 Jeremy Lewis, Shades of Greene: One Generation of an English Family (London: Vintage, 2011), 232-3, 277-8, 284-6, 295-6.

29 Interview, 12.

30 See Dorothy Spencer, 'The Second Vatican Council and the English Catholic Novel' (Unpublished PhD Thesis, University of Liverpool, 1996). 
is convinced, through extended conversation with Vivian Greene, that it was rather the husband who strenuously resisted the end of the affair. ${ }^{31}$ This prioritization of truth telling, of authenticity at whatever cost, an aversion to hypocrisy and a slight sense of persecution emerge as key leitmotifs and intellectual priorities in Dr Bieżanek's own biography.

The bare facts of Anne Bieżanek's life- though completely unknown today - were daily fare for a 1960s newspaper reading and television viewing public. From the completion of a medical degree at the University of Aberdeen and the commencement of her medical practice in psychiatry in 1951, alongside her early marriage age to Jan Bieżanek (a Polish émigré and former judges advocate, then merchant seaman), most explanations of her public activities in the early 1960s dwelt on the string of ten pregnancies and seven children in thirteen years which led her to question the Catholic Church's reproductive teaching. She herself was complicit in this public-fashioning, presenting herself in the media as a respectable (but beleaguered) mother and professional woman, the victim of draconian and irrational dogma, which led inexorably to a questioning of the Church's position and an inevitable confrontation with the Church authorities. These character outlines are fully sketched in her own book and inform all subsequent renderings - such as the brief discussion of her clinic in Bernard Asbell's 'biography' of the pill and Lara Mark's history of contraception. ${ }^{32}$ Asbell's representation of Dr Bieżanek as a 'wild woman', including his descriptions of her as 'tall, handsome, and blond ... intense [and with] a tongue like a whip'33 was replicated - under the chapter heading 'Rebel with a Cause' - in Christine Dawe's recent biographical sketches of prominent Merseyside personalities. ${ }^{34}$ In these portraits, constructions of femininity, maternity and celebrity are mobilised to situate Dr Bieżanek's protest within the gendered landscape of sexual politics, and a 1960s assault on religious orthodoxy. Such framings are particularly prominent in the television reporting (and photographic representations) of her rebellious reception of Holy Communion at Westminster Cathedral in May 1964, which will be examined in more detail.

Dr Bieżanek's biography ultimately escapes, however, such neat categorization. On the one hand, rhetorical modes common in women's autobiographical writings are present, ${ }^{35}$ such as her

31 Interview, 12.

32 Bernard Asbell, The Pill: A Biography of a Drug that Changed the World (London: Random House, 1995), 214-25, 320-1, 325; Lara Marks, Sexual Chemistry: A History of the Contraceptive Pill (London: Yale University Press, 2001), 11, 269-70 (fn23); figure 2.

33 Asbell, The Pill, 214.

34 Christine Dawe, 'Dr Anne Biezanek' in Merseyside's Own (Stroud: History, 2012), n.p.

35 For an exploration of these themes within the interwar autobiographies of British women writing about marriage and romantic intimacy, see Barbara Caine, 'Love and Romance in Interwar British Women's Autobiography', in Harris and Jones, Love and Romance, 20-41. 
disclaimer of scholarly expertise and originality, ${ }^{36}$ an appeal to emotional authenticity, and a relational (and classed) impulse to write in solidarity for other women 'very few of whom were likely to be as well equipped as I in physical and educational resources. ${ }^{37} \mathrm{Her}$ author's note, on the opening pages, evoked the writing process at the family's holiday cottage in Cornwall, with her seven children entertained by their grandmother to facilitate the necessary quietude and leisure. Directly addressing the reader, she disclaims:

do not look for polished writing or the well-turned phrase. This book simply pours forth under its own momentum, with every word coming straight from the heart. ${ }^{38}$

And later on:

If I can help anyone with these reflections of mine then I am only too glad to do so, and it will help me to come to terms with the unspeakable bitterness and suffering I have myself endured on this matter.... 39

Recalling Canon Drinkwater's analogy with Newman, All Things New is a revealing spiritual autobiography and psychological portrait of its author. The opening chapter narrates the fervour and emotional intensity of her conversion, her naïve, romanticised attraction to wartorn Poland (and by extension to its national faith and refugees), and the desire to commit unequivocally and zealously to her new faith. Only against this backdrop is it possible to understand fully the agonized wrestling with conscience and Church teaching that underpinned her decision to take the pill on prescription in 1962 and then open a clinic for Catholic wives the following year. The book is also remarkable in its fearless and, at that time, profoundly countercultural discussion of mental illness - encompassing Dr Bieżanek's work in psychiatric institutions throughout England in the 1950s and her encounter with patients tortured by religious 'scruples', ${ }^{40}$ through to her own confession (omitted in other biographies) of her breakdown and self-committal to an Edinburgh mental hospital when pregnant with her sixth child. ${ }^{41}$ In an ironic sense, and one that she herself might not have acknowledged, Dr Bieżanek's autobiography might be incorporated into the tradition of mid-twentieth century Catholic novels in its interrogation of a culture of sin, guilt and the contortions of conscience. ${ }^{42}$ Another Shade of Greene to add to the family album.

36 Bieżanek, All Things New, 133.

37 Ibid, 16

38 Ibid, 9.

39 Ibid, 132.

40 Ibid, 35.

41 Ibid, 15, 40-1.

42 Mark Bosco, Graham Greene's Catholic Imagination (Oxford: Oxford University Press, 2005); Adam Schwartz, The Third Spring: G. K. Chesterton, Graham Green, Christopher Dawson, and David Jones (Washington: Catholic University of America Press, 2005). 
Yet the theological sophistication of Bieżanek's book and its frank and revealing self-analysis marks it out from Graham Greene's oeuvre. To this end, the second half of the book is a spiritual treatise which undertakes a scholarly but accessible reconceptualization of Catholic teachings on birth control through the lens of the Bible, the writings of St John of the Cross and popular Mariology. Taking her title from the final book of the New Testament, ${ }^{43}$ apocalyptic strains and the conceptualization of the current crisis as 'birth pangs' of a new order infuse the writing. Within Dr Bieżanek's rending of the 'revolution' unfolding, ${ }^{44}$ there is a presentist, post-war democratic impulse to the analysis. The ideological fascism of the Nazis (and their treatment of Poland) is always in view, ${ }^{45}$ and resistance to the 'spiritual totalitarianism' of the institutional Church, ${ }^{46}$ alongside a rightly understood theology of women's nature and married love free of past distortions, is presented as a just war or judgment day. ${ }^{47}$ In an inclusive, cross-class rallying call, Dr Bieżanek acclaimed:

This is not a battle of kings and princes; this is the battle of the common folk and the little people. This is THEIR battle; the issue of their right to be themselves; the sources of the conflict are their own secret nightmares; the outcome is to be one that expresses the might of the living God within them. ${ }^{48}$

It is, therefore, conceived as another 'people's war' or further proof of the flourishing of a vibrant democratic culture in Britain, using salient language of the day. ${ }^{49}$ Articulating a broader priority in post-war Catholic popular piety on an incarnational, this worldly, Christology of CAFOD rather than the cross, ${ }^{50}$ Dr Bieżanek pithily framed these preoccupations, in language directly reminiscent of John Robinson's contemporaneous best seller 'Honest to God', ${ }^{51}$ through the birth control issue:

43 Apocalypse, Chapter $21: 1-5$ is cited in full in the preliminary pages of Bieżanek, All Things New, 10.

44 Bieżanek, All Things New, 131-2.

45 Ibid, 15.

46 Ibid, 99.

47 Ibid, 135.

48 Ibid, 93 (original emphasis).

49 See Angus Calder, The People's War: Britain 1939-45 (London: Cape, 1969).

50 Alana Harris, 'Gatherings at the Family Table: Transformations in Christology and Popular Religiosity in Twentieth-Century English Catholicism, 1945-80' in Tine van Osselaer and Patrick Pasture, eds. Christian (Homes Religion, Family and Domesticity in the 19th and 20th Centuries (Leuven: KADOC, 2014), 178-206.

51 I am grateful to Sam Brewitt-Taylor for this observation, and for pointing out the prevalence of eschatological language (and biblical quotations from the Book of Apocalypse) as recurrent motifs in radical Anglicanism of the early 1960s, including in David Edwards' introduction to Honest to God (1963) and as the title of the World Council of Churches' conference in 1968. 
Few are any longer interested in heaven 'up there'. All are hungering for the 'living bread that came down from heaven.' We want our heaven on earth, and why should we not? ${ }^{52}$

Drawing upon newly-circulating pamphlets such as the Dominican Victor White's God and the Unconscious (1952), Dr Bieżanek interwove Old Testament references to Israel's suffering and exile, with reflections on the prophetic voice today in the 'anathematized ... coming under the care of psychiatrists' or recognition of a 'hypothetical Christ, hidden in my very real, "Baptist-like" patients. ${ }^{53}$ The voice crying in the wilderness, but with some expectation of the inauguration of a wider movement, is her characterization of her own near-messianic cri de coeur. In Dr Bieżanek's explanatory schema, the mysticism of St John of the Cross - which she acknowledged fifty years later remained a source of spiritual sustenance - explained the present-day crisis in the Catholic Church. ${ }^{54}$ As the counter-reformation Carmelite mystic affirmed, 'to attain the supernatural knowledge, which is the daylight of heaven, the soul must [first] traverse this night. ${ }^{55}$ The acrimony and confusion surrounding the Church's position on sex and contraception, particularised in its treatment of herself as a spokesperson for countless suffering Catholics should, she asserted, 'be welcomed as a sign of great portent. ${ }^{56}$

The analytical framework that sustained Dr Bieżanek's wholesale critique of traditional natural law ethics and its restatements (such as Pope Pius XI's 1930 encyclical Casti Connubii) was her appeal to a very 'high' Mariology — indeed the controversial proposition intensely debated (and by November 1964 narrowly rejected at the Second Vatican Council) of Mary as Co-Redemptrix. ${ }^{57}$ Seeing off what she saw as squeamish ecumenical qualms about Mary as a 'barrier to reunion' then fashionable in liberal Catholic circles by disparaging them as the concerns of "an "all boys together" kind of tea party, ${ }^{58} \mathrm{Dr}$ Bieżanek urged Catholics to recognise the fragmentation of Christian truth at the Reformation and to embrace their safekeeping of a unique part of revelation history which 'is giving to the woman, the mother of

52 Bieżanek, All Things New, 130.

$53 \mathrm{Ibid}, 33$ and 35.

54 Bieżanek, All Things New, 138-40; and post-interview correspondence 5 November 2010 (in author's possession).

55 Bieżanek, All Things New, 138.

56 Ibid, 140 .

57 For a discussion of Marian discussions at the Second Vatican Council, see Melissa Wilde, Vatican II: A Sociological Analysis of Religious Change (Princeton: Princeton University Press, 2007), 102-115 and Alana Harris, "Your influence and advice will be called on copiously": Abbot Christopher Butler OSB and the English at the Council' in Christian Sorrel, ed. Religieux et Vatican II (Leuven: KADOC, forthcoming).

58 Bieżanek, All Things New, 141. 
Christ, a status in the scheme of salvation equal to that of her son. ${ }^{59}$ As she asserted:

Christ's work of redemption cannot be separated from the work of His mother, who under the providence of God literally made Christ's advent possible, and translated it from a prophecy to a reality, by her willingness to fulfil the destiny that had been laid upon her. ${ }^{60}$

Eschewing what she thought a facile (and conceptually problematic) identification of Mary as a mother like all Catholic mothers, Dr Bieżanek's reasoning remained grounded in the theological implications to be drawn from the Nazareth story. The Church's teaching on Mary's perpetual virginity, alongside the incarnation narrative, led her to recognise:

in the matter of the conduct of her marital relationship it is clear that she has no specific message to give her spiritual children, for her marriage was unique. ... But from her willingness to launch forth in a spiritual adventure of the first magnitude there are many conclusions to be drawn. ${ }^{61}$

One telling conclusion, for the purposes of her current argument, was the implications flowing from Mary's recognition as a 'Second Eve'. Meshing popular Mariology to modern technology, she claimed:

the advent of oral contraception appears to me to be an event of as great a significance for mankind as was the expulsion from the Garden of Eden ... The contraceptive pill has come to woman, as a heavenly reprieve from that primordial doom. It is my contention that this must be willed by God, and I say that the appearance of these drugs can be taken as a sign of God's final pardon ... [a] reprieve for the daughters of Eve ... won for them by 'the Second Eve'... ${ }^{62}$

As this section of her treatise concluded, 'it is through a knowledge of the Virgin Mary that Roman Catholic men will learn to honour all women, and bring the days of their neglect to an end'. ${ }^{63}$ In the years that followed, particularly in the discussions surrounding the Pontifical Commission on Birth Control and hoped liberalization of the Church's teaching (which were to be unequivocally dashed by Pope Paul VI's encyclical), compassion, pragmatism and appeals to 'secular', rational and scientific reasoning were foregrounded. ${ }^{64}$ Dr Bieżanek's inventive, if ultimately unsuccessful contribution to this debate, was to try to offer a rhetoric of continuity, a mechanism to reconcile the accumulated (prohibitive) Church teaching with the undergirding authority of tradition and the sensus fidelium as a

59 Ibid, 143.

60 Ibid.

61 Ibid, 144.

62 Ibid, 145-6.

63 Ibid, 148

64 For a brief discussion, see Harris, Faith in the Family, 162-166. 
'source' for Christian development. In her attempt to circumvent the polarization of the debate into factions (traditionalist and progressives) and the juxtaposition of obedience and conscience, All Things New offered an avenue through the impasse - a way 'the whole hierarchical paraphernalia is going to survive the massive kick in the teeth it would receive if and when an official "about turn" is forced on it ${ }^{65}$ Traditional hierarchies and unquestioning deference to authority did not, of course, survive the Catholic Church's spiritual '68 - in common with the experience of other Western European institutions in this decade. ${ }^{66}$ Nor did Dr Bieżanek's embattled commitment to the Catholic Church endure into the 1970s, for in being rendered a non-communicant she felt she was 'sort of ex-communicated by the back door you might say'. ${ }^{67}$ Negotiating the personal implications of her stance with her husband, her local parish, her Diocesan Bishop and ultimately with the President of the Bishops' Conference of England and Wales, she eventually found a new spiritual home in Pentecostalism, homeopathy and biblical study facilitated by the Open Bible Ministries. ${ }^{68}$ It is these relationships, and her correspondence in the early 1960s with these men in authority, which will now be examined.

'Shouting from the rooftops' about things done in sacred places: the letter and the spirit of the law

In her first epistle within an extensive correspondence that lasted over three years, Dr Bieżanek's opening letter to the Bishop of Shrewsbury ${ }^{69}$ on 13 February 1963 ran in the formulaic terms usually found within the confessional:

In the last 12 months I have run into difficulties in my married life that have compelled me to take extraordinary steps. Steps at variance with my conscience and the teaching of the Church. My reason for acting thus has been the protection of my own health and sanity and thereby the protection of the life of the family. ${ }^{70}$

65 Bieżanek, All Things New, 83.

66 Rebecca Clifford, 'The Church in Crisis: Catholic Activism and "1968", Cultural and Social History 8, 4 (2011): 531-50; Robert Gildea, James Mark and Annette Warring, eds. Europe's 1968: Voices of Revolt (Oxford: Oxford University Press, 2013); Gerd-Rainer Horn, The Spirit of '68: Rebellion in Western Europe and North America, 1956-1976 (Oxford: Oxford University Press, 2007); Gerd-Rainer Horn, The Spirit of Vatican II: Western European Left Catholicism in the Long Sixties, 1959-1980 (Oxford: Oxford University Press, 2015).

67 Interview, 4.

68 Ibid, 30 and 32.

69 For biographical information on Bishop Eric Graser see Brian Plumb, Arundel to Zabi: A Biographical Dictionary of the Catholic Bishops of England and Wales (Deceased) 1623-1987 (Wigan: North West Catholic History Society, 2006).

70 Letter from Anne Bieżanek to Bishop Eric Graser, 13 February 1963, GRAS/AB/SDA. 
Implicit within this personal introduction and the outline of her spiritual and marital situation is Dr Bieżanek's decision to commence taking the pill — which she dated very precisely to 25 May $1962^{71}$ —and the consequences of this decision in her parish many months later when she was publicly refused Holy Communion at the altar rail. The escalation of this marital decision from a subject of conversation with her priest, to a matter made public at the altar rail and elevated to the Bishop's correspondence tray, is illuminating of the ways in which Dr Bieżanek melded traditionalist conceptions about marriage (and unrestrained, brutish male sexuality) ${ }^{72}$ with progressive and psychological-informed constructions of women's sexual desire, ${ }^{73}$ female agency and a marked anti-authoritarianism. For Dr Bieżanek, who fifty years later said that she didn't feel any connection to feminism ${ }^{74}$ yet referenced in print the 'liberated feminist with her vote, her education, her legal rights and her dutch cap, ${ }^{75}$ the personal was indeed political or perhaps, more precisely, theological. The politicised arena in which Dr Bieżanek concentrated her reforming challenge, the social body that she sought to reconfigure with reference to her own embodied, experientially-framed insights, was what she identified as the Catholic Church's misogynistic understandings of gender equality and sexual relations.

Reconstructing the chronology of events from a voluminous correspondence, the difficulties for all parties seem to have arisen in early 1962, when Dr Bieżanek confided her extreme difficulties negotiating her husband's insistent and sometimes violent demands for unfettered sexual intimacy to her assistant parish priest, Father Gaskell. ${ }^{76}$ Fearful of yet another pregnancy, but equally scared of the intense disruption to marital stability caused by sexual abstinence, she asked for an alternative line of conduct. Father Gaskell is reported, in All Things New, to have refused to help Dr Bieżanek separate from her husband and, moreover, to have advised that in taking the contraceptive pill she would be refused Confession and Communion. ${ }^{77}$ Distressed by this impasse, his response to her question 'What then am I to do?' was 'I do not know' ${ }^{78}$ Elsewhere in her letters to the Bishop, Dr Bieżanek

\footnotetext{
71 Bieżanek, All Things New, 51

72 E.g. Ibid, 17 and 113.

73 Ibid, for a discussion about women's desire for vaginal orgasm (87-89), female sex drive (95), and the recognition of sex as a good in itself (106).

74 See Interview, 25: 'Well, it [the feminist movement] all seemed-I was always too busy, I mean I was a doctor, a mother, and what have I got to do with feminism?'

75 Bieżanek, All Things New, 73 See also Bieżanek to Graser, 21 July 1963, 2, GRAS/AB/ SDA, reflecting on women's new capacity to 'design a bridge, visit the moon, become a high court judge or adopt a family of abandoned Chinese children ... [Yet] she cannot do any of these things and have children of her own at the same time.'

76 Bieżanek to Graser, 13 February 1963, 1, GRAS/AB/SDA.

77 Bieżanek, All Things New, 51

78 Ibid.
} 
acknowledged the pastoral care and support that Father Gaskell had offered - he "has always been very kind and generous in the help he has given $\mathrm{me}^{, 79}$-alongside her appreciation for his own 'extreme nervous discomfiture' requiring 'for his sake, as much as my own, that the matter ... be taken further. ${ }^{, 80}$ This young priest's difficulties in explaining and enforcing the Church's teaching on contraceptive practice would be echoed in a number of high-profile cases of clerical dissent in the years that followed, ${ }^{81}$ anticipating the so-called 'northern rising' of clergy in the Archdiocese of Liverpool who failed to toe the line on Humanae Vitae in 1968. In the heartland of traditional and resurgent Catholicism (and, intriguingly, the early twentieth-century birth control movement), working-class Catholics and their clergy were at the forefront of a revolt deemed one of the most intense in Western Europe. ${ }^{82}$

In the months following May 1962, when Dr Bieżanek had started practising contraception, she reportedly refrained from receiving Holy Communion when attending Mass each week at her parish Church, St Alban's. As she recounted in All Things New, this stance raised delicate questions from her children, and particularly her eldest daughter who had just started to receive Holy Communion. ${ }^{83}$ Resolving to regularise her situation, she therefore wrote to the priest-in-charge, Canon George Higgins, announcing her intention of receiving Holy Communion along with my daughter on December $8^{\text {th }}$ [1962], the first anniversary of her First Holy Communion'. She concluded this letter by stating that despite Father Gaskell's ruling that her 'peculiarities ... [prove] an absolute impediment to my reception of the Blessed Sacrament ... I do not share his opinion and mean to carry on in spite of it'. ${ }^{84}$ The letter closed by saying that Father Gaskell's 'misplaced sense of delicacy' may have prohibited discussion of the circumstances of her case, but she now felt that she had to face the difficulties directly. ${ }^{85}$ As she later reported on this course of events to her Bishop, she left the "way open for him to take any steps he thought right, to prevent or dissuade me. ${ }^{, 86}$ Dr Bieżanek's letter did not receive an acknowledgment, and the following Sunday, she went to the communion rail, as she then did every Sunday following.

This appearance of equanimity and conformity-perhaps echoing the practice of more English Catholics than previously appreciated if

79 Bieżanek to Graser, 13 February 1963,1, GRAS/AB/SDA.

80 Ibid, 3 .

81 E.g. Arnold McMahon (Diocese of Birmingham) and Joseph Cocker (Isle of Wight). On the former, see his article 'Authority and the Catholic Church', Birmingham Post, 19 February 1965, 8 and 'RC Priest Pleads for Birth Control', Daily Mail, 20 February $1965,1$.

82 'UK reaction most intense', Catholic Herald, 23 August 1968, 2.

83 Bieżanek, All Things New, 53-4.

${ }_{85}$ Letter Anne Bieżanek to Canon George Higgins, 2 December 1962, 1, GRAS/AB/SDA.

85 Ibid.

86 Bieżanek to Graser, 13 February 1963, 2, GRAS/AB/SDA. 
the letters in the concluding pages of All Things New are any guide ${ }^{87}$ was ruptured by an announced parochial visit by Bishop Eric Graser in February 1963. At this time Dr Bieżanek communicated to Canon Higgins her desire to seek a private meeting with the Bishopostensibly to talk about his 1961 pastoral letter on the need for a moral crusade and, in a Mary Whitehouse vein, ${ }^{88}$ the sexualizing effects of 'degrading film and literature' on 'Catholic husbands'. ${ }^{89}$ Fearing the consequences of such a meeting - and perhaps censure of his 'turning a blind eye' at the communion rail each week-Canon Higgins preemptively wrote to his Bishop on 13 February 1963. His summation of Dr Bieżanek and the parochial situation was as follows:

[She] is married to a Pole, a sailor, who is away on long trips. She herself is a doctor, a psychiatrist, and has spent one long period in a mental home as a patient. I have typed out and enclose part of a letter she wrote to Fr Gaskell. From its contents you will be able to judge her to some extent. There are other things which you ought to know but I find it difficult to put it down on paper, but I do hope that you will be very wary in whatever you decide to do. None of us here want to have anything to do with her. ${ }^{90}$

The letter annexed was indeed a curious (and intimate) piece of correspondence written by Dr Bieżanek a month earlier which, in a mystical and metaphorical vein, claimed that Father Gaskell was the spiritual 'father of [her] bastard child' - by which it is clear she meant her resolve to 'stir something up' and which ultimately was 'delivered' as her birth control clinic. ${ }^{91}$ Canon Higgins' reluctance to 'put down on paper' the intricacies of her marital difficulties is also in marked contrast to Dr Bieżanek's own candour in correspondence and, as Adrian Bingham has explored, the increasing willingness generally of the British public to speak and read about sexuality in print. $^{92}$

Read without any background context, nor a sense of Dr Bieżanek's rhetorical flourish, Canon Higgins' intervention was clearly an attempt to discredit his parishioner's approach and indeed cast aspersions on her sanity. Dr Bieżanek's persistence in seeking an appointment with

87 Bieżanek, All Things New, 155-72 and 99. See also the assessment of Katharine Whitehorn, Observer journalist and daughter of Herbert Grey, founder of the National Marriage Guidance Council, 'Catholics and Birth Control, Family Planning, 13, 1 (1964): 6-7.

88 Lawrence Black, 'There was Something about Mary: the National Viewers' and Listeners' Association and Social Movement History' in Nick Crowson, Matthew Hilton and James McKay, eds. NGOs in Contemporary Britain: Non-State Actors in Society and Politics Since 1945 (Basingstoke: Palgrave, 2009), 182-200.

89 Bieżanek to Higgins, 9 February 1963, 2, GRAS/AB/SDA

90 Higgins to Graser, 13 February 1963, GRAS/AB/SDA.

91 Letter from Anne Bieżanek to Fr Gaskell, 14 January 1963, GRAS/AB/SDA.

92 Adrian Bingham, "The "K-Bomb": Social Surveys, the Popular Press, and British Sexual Culture in the 1940s and 1950s', Journal of British Studies, 50, 1 (2011): 156-79. 
the Bishop drew a sharp letter from Canon Higgins, which he copied to the Bishop on 21 February 1963 with the covering note:

Please do not be perturbed by the apparent severity of this letter. ... This woman has been told that she should not go to communion-she will not accept the teaching of the Church on a serious moral matter. She receives communion and we can do nothing, but that does not mean that I cannot show my abhorrence of her conduct in some way or another. ${ }^{93}$

Expressed in specific form, here is another instance of clerical discomfort with the 'writings' and witness of 'querulous women', alongside assertions of powerlessness to enforce conformity with the Church's official stance. Meanwhile Dr Bieżanek's first letter to Eric Graser, which closed with assurances of her 'most earnest determination to act correctly, ${ }^{94}$ had brought the matter squarely to the attention of the Bishop of Shrewsbury.

Bishop Graser proceeded to have a meeting with Dr Bieżanek during the course of his February parochial visitation, but rather than containing the situation, their conversation seems to have hardened the lines of opposition. Writing shortly thereafter on 25 February 1963, Dr Bieżanek thanked the Bishop for his time, courtesy and patience, but her placatory expressions of two weeks earlier had evaporated and been replaced by her own articulation of what 'acting correctly' and authentically might entail:

... I do not accept your self-appointed right to act as judge, jury and executioner in this matter, a matter that involves not only the stability of my home but the destiny of my immortal soul and those whom providence has appointed me to influence.

I do not think that you can afford to ignore me ... warn your fellow bishops, as soon as possible, that the Church must needs look to her defences in this matter. The Catholic mother is the heart of the Church. That heart is exposed and has already been pierced. It now requires particular attention or it will stop and die.

If the bishops will not look to this, then I will do so myself on my own authority.

You suggest that there is something "unsporting" in my putting the parish clergy in the spot I have put them in. But this is no game. Everything is at stake. ${ }^{95}$

Drawing upon longstanding Catholic rhetoric about the centrality of mothers to the inculcation of the faith and implicitly to devotion to Mary of the Sacred Heart, Dr Bieżanek's diagnosis of the damage done to the Church through its stance on contraception resonates with the assessment of historians of the sixties who have interrogated the

93 Higgins to Graser, 21 February 1963, GRAS/AB/SDA.

94 Bieżanek to Graser, 13 February 1963, 3, GRAS/AB/SDA.

95 Bieżanek to Graser, 25 February 1963, 1-3, GRAS/AB/SDA. 
importance of women's alienation to the wholesale religious crisis of the period. ${ }^{96}$ Yet what is equally surprising is the insight this correspondence provides into the shifting and less hierarchical relationship evolving between priest and people in the lead up to the Second Vatican Council. Despite the anger and self-confident defiance of this letter, a regularalmost weekly — and intimate, indeed familiar correspondence continued between Bishop Graser and Dr Bieżanek. Its terms give a practical but highly unusual demonstration of the enactment of concepts such as the 'primacy of conscience', the 'apostolate of the laity' and the renegotiation of clerical authority during this decade. Within this remarkable exchange of letters we see the opposing struggles of two 'devout' Catholics attempting to negotiate diametrically contrasting positions within the landscape of increasingly unstable Church teachings. ${ }^{97}$

Symptomatic of such struggles was a letter Dr Bieżanek wrote to her Bishop on 19 March 1963, in which she formally announced her intention to 'gain a footing in Family Planning Circles' while 'reconcil [ing] my position as a practising Catholic with work of that kind' ${ }^{98}$ In a telling precursor to her theological Mariology in All Things New, she enclosed an essay intended as an 'answer' to the perceived contradiction between her Catholicism and the provision of contraception. Dedicated to St Joseph, the lengthy essay rehearsed the arguments that would later find their way into print. Starting from the premise that there are "two evils', a universal preoccupation with sex alongside universal dread of its procreative consequences, her diagnosis was 'a truly neurotic condition [expressed in] abnormal sexuality'. ${ }^{99}$ Combining psychological analysis, with sociological insights on the wide recourse in marriages to 'unnatural', non-reproductive sexual acts (chiefly coitus interruptus and anal sex), ${ }^{100}$ Dr Bieżanek takes as her lead 'those spokesmen' of the

96 McLeod, The Religious Crisis of the 1960s (Oxford: Oxford University Press, 2007), $163-4,166,181$ is skeptical of the part played by feminism and sex in the rejection of religion in the 1960s, cf Callum Brown, 'Women and Religion in Britain: The Autobiographical View of the Fifties and Sixties" in Callum G. Brown and Michael Snape, eds. Secularisation in the Christian World (Farnham: Ashgate, 2010), 159-73 who postulates a strong and unequivocal correlation.

97 For an insight into Bishop Graser's sympathetic but constrained perspective on the case, see Letter from Bishop Eric Graser to Canon Harold Drinkwater, 12 March 1966, GRAS/ AB/SDA: 'The case of Doctor Biezanek is a very sad one; you are not the first to ask me to allow her to receive the Sacraments. If I could do this I would be more than happy, but I do not see how I could be justified in doing so. I had read in the Tablet what Cardinal Döpfner has said but I still cannot see my way to changing my decision. Let us hope it will not be long before we receive a statement from His Holiness.'

98 Bieżanek to Graser, 19 March 1963, 2, GRAS/AB/SDA.

99 Ibid, Annexure, 1, GRAS/AB/SDA.

100 See Szreter and Fisher, Sex Before the Sexual Revolution, 229, 231 (58\% of the authors' interviewees used withdrawal as a form of contraception). On anal sex, see Szreter and Fisher, Sex Before the Sexual Revolution, 231(fn6) who suggest it was not widely practised, cf. Eustace Chesser, Sexual Behaviour, Normal and Abnormal (London: Medical Publications Ltd, 1949), 183 who reported a figure of $15 \%$ of his patients in the interwar period who used this technique to avoid conception. 
Church who piously diagnosed 'recourse to the Virgin Mary' for spiritual aid. ${ }^{101}$ What follows is a schematic outline which would be later developed, with the historical Miriam of Nazareth held up as neither 'model or guide' not least because of St Joseph. Hailed as 'certainly a marvel' in his 'profound respect for his spouse and selfeffacement', ${ }^{102}$ she continued:

Mary's virginity was in his keeping and he kept it ... She had but one child and a husband who made no demands on her. ${ }^{103}$

Developing out the dogma of Co-Redemptrix, alongside a low estimation of most men's capacity for sexual restraint and selflessness, ${ }^{104}$ she concluded her essay more trenchantly than her autobiography: 'Men have had the running of the world until now and the world is all but lost. It will be saved again by women and through women. ${ }^{105}$ Without commenting on the essay's admixture of theology and proto-feminism, Bishop Graser's response three weeks later was short and direct: 'The main thing on which your essays rests is the doctrine of Our Lady as Co-Redemptrix, however, and unfortunately this has been misunderstood. ${ }^{106}$ After critique of her assertions on the incarnation and atonement theology, he concluded 'the essay rests on a false foundation, giving rise to mistaken conclusions ... it would be inadvisable to distribute the essay since it would be misleading. ${ }^{, 107}$ Indeed, as Dr Bieżanek would herself come to realise, ${ }^{108}$ in founding her vision of sex reform and female marital liberation (within discrete bounds, as she was a political and social conservative on other issues) ${ }^{109}$ on an undefined teaching of the Church, her programme for reform and renewal remained captured within institutional logics and was scuppered, upon its birth, in a rapidly shifting theological scene.

The correspondence that Bishop and laywoman exchanged through the spring of 1963 mostly consisted of Dr Bieżanek updating 'dear Eric' on her Family Planning Training in Birkenhead and describing the Catholic women who came to her for help in fitting diaphragms without their husband's knowledge. As she concluded in a letter in May:

Things that are done in sacred places are going to be shouted from the house-tops.

101 Bieżanek to Graser, 19 March 1963, Annexure, 2, GRAS/AB/SDA.

$102 \mathrm{Ibid}, 4$.

103 Ibid.

104 See Bieżanek, All Things New, 72, 95-6, 113.

105 Bieżanek to Graser, 19 March 1963, Annexure, 7, GRAS/AB/SDA.

106 Graser to Bieżanek, 5 April 1963, GRAS/AB/SDA.

107 Ibid.

108 Interview, 9 and post-interview correspondence 31 October 2010 (in author's possession).

109 See the post for 30 November 2010 for a brief discussion of her staunch support of the Wallasey Conservatives, https://leahfraser.wordpress.com/category/people/page/2/ (accessed 24 June 2015). 
Do I need to add that you and Archbishop Heenan between you (and particularly the latter) are going to have a first class crisis on your hands?

Today is the Feast of the English Martyrs and I know what I am about. May I make this last appeal to you to meet me this month and discuss what is to be done for the best? ${ }^{110}$

This appeal for mediation-which from the Bishop's perspective probably meant greater discretion as well as desisting from opening the clinic - was unsuccessful. In a letter written in July, Dr Bieżanek opened with the statement 'I know that to engage in a project of connivance with me would in fact be impossible, even if you wanted to. You will have to come out into the open, either for me or against me. ${ }^{, 111}$ In an emotional and evocative piece of writing that reads like the ' 95 theses', she concluded:

So it will have to be the other thing: open war. ... There is nothing personal in this, it is just the necessity of the situation. ...

My declaration of war takes this form: I intend to run, from this house, a private clinic for the purpose of helping Catholics overcome their matrimonial problems. I do this on my own authority and stand between them and anything the clergy choose to say to them on the subject ... I am not one little bit afraid of you or the machinery behind you. You will, all of you, break your teeth on me. ... In order to get this over as quickly as possible, I wish you would advise me as to the minimum amount [sic] of public provocation I need to give you, to justify your public intervention.

A notice nailed to the Church door announcing the opening of such a clinic? ${ }^{112}$

Even the opening of her clinic two months later in September, dedicated to Spanish mystic and healer St Martin de Porres and her reception of a stream of Catholic clients in the early months, did not itself openly constitute an 'act of war' (figure 2).

It was rather the report within November's Daily Mail—with which this article opened - and a short interview on Granada TV's 'Scene at 6.30', which prompted Canon Higgins publicly to refuse her Communion on 1 December 1963 with the loud, public statement 'You don't get it'. ${ }^{113}$ In the weeks following, other parish priests similarly passed her over at the altar-Father McManus saying 'pardon' when doing so, and the Daily Mail reporting 'crowds gathered around her when she left at the end of the service', mostly to offer 'support' and 'encouragement'. ${ }^{114}$ These events were, however,

110 Bieżanek to Graser, 4 May 1963, 2, GRAS/AB/SDA.

111 Bieżanek to Graser, 18 July 1963, 1, GRAS/AB/SDA.

112 Ibid, 2-3.

113 Bieżanek, All Things New, 60 and 'Sacraments Refused to Woman Doctor', The Times, 13 January 1964, 5.

114 'Communion Ban on Birth Control Doctor', Daily Mail, 13 January 1964, 3. 


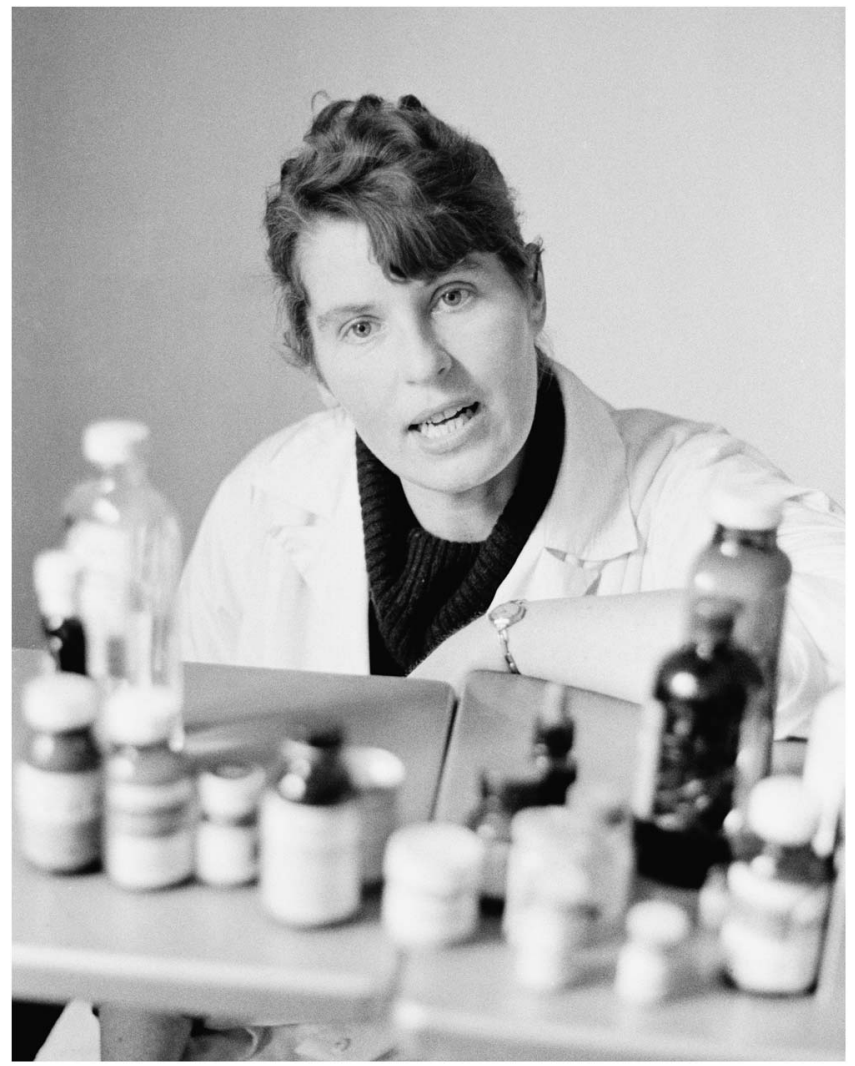

Figure 2. A confident, forthright Anne Bieżanek in her dispensary. Permission granted by Getty Images.

the breaking point for her husband Jan-in All Things New she described his contentment with her contraceptive arrangements until 'the public rebuff', which he felt as a form of corporate shaming, branding her as a heretic, whore and sinner. ${ }^{115}$ For Jan, as for Canon Higgins, it was the publicity - the airing in public of things that were 'secret and sacred'-which elicited acts of outrage and vengeance. What also followed was a very public dissection, ${ }^{116}$ an almost 'kitchen-sink drama' of their marital difficulties. The Daily Mail reported in January 1964 that 'Husband drops Ultimatum on

115 Bieżanek, All Things New, 61-2. See also Interview, 3 where Dr Bieżanek describes Jan's humiliation at his wife's bar from Communion as 'that only happens to whores and things' and his ultimatum that she close the clinic and publically apologise to the Bishop.

116 It is telling, however, that Dr Bieżanek's employment and marital difficulties in the early 1960s did not draw the same vitriolic and misogynistic censure heaped upon Margaret Knight in her dealings with the press - see Callum Brown, "The Unholy Mrs Knight" and the BBC: Secular Humanism and the Threat to the Christian Nation, c.1945-60', English Historical Review, 127 (2012): 345-376, 362-4. 
Clinic', ${ }^{117}$ only to be followed in May by 'My marriage had broken up, says Birth Control doctor'. ${ }^{118}$

Something of the same 'keeping up appearances' mentality was present in the Diocese's position on the clinic and its proprietor, who were now firmly thrust into the media spotlight. In official correspondence to 'my dear Mrs Bieżanek', Bishop Graser reiterated the Church's official line of retraction, repentance and restitution to make good the public scandal caused. ${ }^{119}$ In correspondence exchanged in April 1964, following a suggestion that she could attend Mass and receive Communion in Churches in nearby Liverpool (which were not under Bishop Graser's jurisdiction), ${ }^{120}$ Dr Bieżanek expressed disquiet that it would be 'wrong' to 'work a fiddle over territorial boundaries and take advantage of things that haven't been said [publicly] by other Bishops'. ${ }^{121}$ She concluded her correspondence by observing that: 'it would involve me in what would amount to a conspiracy to treat you as an amiable lunatic ... and dissimulate in order to protect [sympathetic] priests' by putting the 'letter of the law, on boundaries of authority, over the spirit.' ${ }^{122}$ Implicit within her own phraseology, in its discussions of 'lunacy', is the ambiguity latent throughout the clerical correspondence and tabloid reports about Dr Bieżanek's sanity, and whether her dramatic intransigence on this issue was vanity, mental instability or the prophetic voice of 'Catholic modernity'. Speaking nearly fifty years later about a late evening conversation around April 1964 with the Bishop's representative, Dr Bieżanek recalled:

He said: 'No, we don't want you closing, you mustn't close your clinic', [as] 'we'd be accused of twisting your arm.' And I said: 'well, I sort of have a feeling you are, you know?' And he said 'well, you can't possibly [close], no, no'. He said, he'd worked it out, he said the only think I could do ... was that I ... could go to Mass and seek Communion provided I wasn't recognised. But if anybody told that priest 'oh, there's that woman', they'd have to refuse me. ... And I thought to myself, 'do I want to be in communion with these guys? They're absolute heretics, they're ghastly! Ghastly'. ${ }^{123}$

\section{The body of Christ and women's bodies: sexual politics in Westminster Cathedral}

The duplicity and hypocrisy implicit in these clerically proffered, pragmatic solutions to her dilemma galvanized Dr Bieżanek's last

117 'Husband drops Ultimatum on Clinic', Daily Mail, 23 January 1964, 9. See also 'Marriage Shock for Birth Control Doctor', Daily Mail, 21 January 1964, 9; 'Future of Dr Anne', Daily Mail, 22 January 1964, 3.

118 'RC Birth Control Dr Says: My Marriage is Broken', Daily Mail, 24 April 1964, 1.

119 Graser to Bieżanek, 9 December 1963, GRAS/AB/SDA.

120 Dr Bieżanek had indeed previously commuted into a Liverpool parish (on her scooter!) - see 'Doctor Travels 30 Miles to Beat Communion Ban', Daily Mail, 2 March 1964, 3.

121 Bieżanek to Graser, 11 April 1964, GRAS/AB/SDA.

122 Ibid.

123 Interview, 3. 
public and highly audacious gesture of defiance, which the New York Times described as 'the most publicized and photographed mortal sin ever committed. ${ }^{, 124}$ Within the pages of All Things New, Dr Bieżanek described her earlier interactions with Archbishop Heenan through the 1950s, when he had charge of the See of Liverpool, which centred around her unsuccessful petitions for greater pastoral support for one of his priests under her psychiatric care. ${ }^{125}$ In two colloquial pieces of correspondence to the Bishop of Shrewsbury in July 1963, she recounted a recent visit to Dr Heenan in Liverpool to discuss the soonto-be-opened clinic and her bar from receiving Holy Communion. Describing a 'more agreeable' meeting than anticipated, alongside the Archbishop's disclaimer of 'jurisdiction over the whole of the North of England', ${ }^{126}$ Dr Bieżanek told Bishop Graser that 'Dr Heenan [is] a bit jumpy, ${ }^{127}$ and continued:

To understand that man on this subject you will have to realise that he knows a great deal more about me than I have every told you. He is in a jam and I don't think he is certain of my new found benignity. Come to that, nor am I. It all depends on how I'm treated from now on. If I'm treated like a sensible person, the chances of me behaving like one are enormously increased. ${ }^{128}$

It is against this backdrop of longstanding acquaintance and preexisting enmity ${ }^{129}$ that Dr Bieżanek wrote in February 1964 to Archbishop Heenan - now Archbishop of Westminster - to state the case for a public examination of the Church's position on contraceptive practices. In plain terms she wrote:

It is my intention to force matters into the open in such a manner that others will have to share in thinking out a just solution; and such far reaching moral problems as are at present locked inside my own head (to my own considerable discomforture) should be presented for Universal Consideration. ${ }^{130}$

Seeking to wash his hands of the matter by echoing his previous response that 'my jurisdiction does not extend beyond the Diocese of Westminster', ${ }^{131}$ Dr Bieżanek's responded wryly by 'thanking him for

\footnotetext{
124 'Briton who Heads Birth Control Clinic Defies Ban on Rites', The New York Times, 1 June 1964, 31.

125 Interview, 2-3 and Bieżanek, All Things New, 63.

126 Bieżanek to Graser, 12 July 1963, 1-2, GRAS/AB/SDA.

127 Bieżanek to Graser, 17 July 1963, 5, GRAS/AB/SDA.

128 Ibid (original emphasis).

129 Interview, 2-3, who asserts that after the Westminster Cathedral incident the press were warned off talking to her as a 'person with serious mental health issues' by Archbishop Heenan. Heenan had a strong relationship with many press outlets from his time as Superior of the Catholic Missionary Society (1947-51) - see James Hagerty, Cardinal John Carmel Heenan: Priest of the People, Prince of the Church (Leominster: Gracewing, 2012), 57-78.

130 Letter from Anne Bieżanek to Archbishop John Carmel Heenan, 2 February 1964, 4, GRAS/AB/SDA.

131 Heenan to Bieżanek, 5 February 1964, GRAS/AB/SDA.
} 
[this] knowledge' whilst throwing down the gauntlet: 'Before May is out, I will have invaded your own diocese. May $31^{\text {st }}$ may well see me presenting myself for Communion in your own Cathedral'. ${ }^{132}$ As sex reformers before her had used public confrontations within 'sacralised settings' - parliament, courtroom or Church - to publicise their cause, so too did Dr Bieżanek seek out a stage for this dramatic, climactic gesture. ${ }^{133}$ Writing to the ever-tolerant Bishop Graser, Dr Bieżanek warned him to brace for the 'hurricane' of media publicity as she intended to 'use all modern methods of communication to get the point across'. ${ }^{134} \overline{\mathrm{As}}$ a postscript to the letter she added: 're John Carmel [Heenan], there is only one way of dealing with that boy and that is to thump him when he isn't looking. He can take it alrightwhen it comes in that form. ${ }^{, 135}$

A generalized pre-emptive strike was issued by Archbishop Heenan, speaking for the entire Hierarchy of England and Wales on 7 May 1964, when he issued a pastoral directive reiterating that 'contraception is not an open question', whether by 'pills' or 'contraceptive instruments.'. ${ }^{136}$ In this statement, the Bishops also condemned the doubts sown in the minds of the faithful by imprudent statements questioning the competence of the Church in this particular question. ${ }^{137}$ Disquiet on these issues had been growing from multiple quarters, but Dr Bieżanek publically took up the fight three weeks later through her highly publicised (and photographed) reception of Holy Communion at Westminster Cathedral (Figure 3).

Having written to Archbishop Heenan to announce her intention to attend Mass and describing the clothes she would be wearing so as to be recognised - 'a blue coat and a blue hat' - she presented at the Communion rail on $31^{\text {st }}$ May 1964. She had quite deliberately timed this attendance (and perhaps her wearing of blue), with the Feast of the Queenship of Mary and was given Communion by Canon Victor Gauzzelli. Archbishop Heenan was not present at the service. Speaking after Mass to the throng of reporters and television crews gathered outside the Cathedral, Dr Bieżanek accused Dr Heenan of being a 'moral coward in not facing up frankly to my challenge' and dismissed the Cathedral Authorities' claims that they did not recognise her. ${ }^{138}$

\footnotetext{
132 Bieżanek to Heenan, 16 February 1964, GRAS/AB/SDA.

133 Lesley Hall, "“The Subject is Obscene: No Lady would Dream of Alluding to it": Marie Stopes and Her Courtroom Dramas', Women's History Review 22, 2 (2013): 253-266.

134 Bieżanek to Graser, 16 April 1964, GRAS/AB/SDA (original emphasis). She advertised this confrontation ahead of her journey to Westminster, see 'The Birth Control Doctor Wants to See Dr Heenan', Daily Mail, 27 April, 1964, 9.

135 Ibid.

136 As reported in Richard Whitehead, 'Birth Pills: the Man at the Heart of the Matter' Daily Mail, 8 May 1964, 7 and 'Bishops Take Firm Line on Birth Control: Joint Statement', Catholic Herald, 8 May 1964, 1.

137 Ibid.

138 'Communion Given to Birth Control Doctor', Daily Mail, 1 June 1964, 1.
} 


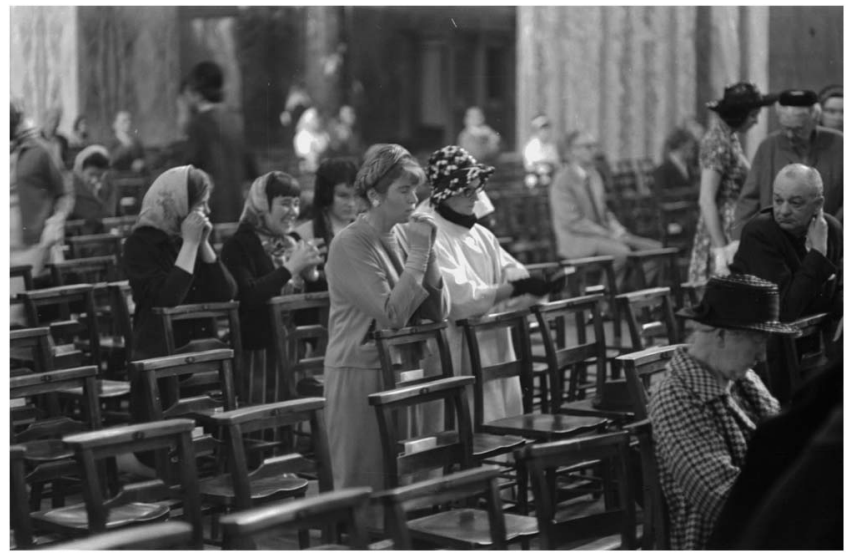

Figure 3. Confrontation in the Cathedral. Dr Bieżanek praying after receiving Holy Communion in Westminster Cathedral, Daily Express, 31 May 1964. Permission granted by Getty Images.

As she reasoned - 'a big fuss was made as I went into the cathedral, and ... there were only a small number of people receiving Communion at the same time as myself. No mistake was possible. ${ }^{139}$ In her deliberately perverse interpretation of these events, her reception of the Blessed Sacrament was deemed a triumph and a sign that the unofficial head of the Catholic Church in England and Wales 'now understands the dilemma of Catholics. ${ }^{140}$

Although she presented herself as a spokesperson for all Catholic women, ${ }^{141}$ particularly those like herself who are 'poor, in a straightforward way' with a large Catholic family, ${ }^{142}$ Dr Bieżanek's activism did not enjoy the cross-class support of all Catholic laity. The Daily Mirror, for example, reported a small group of Catholics outside Westminster Cathedral who heckled her as she emerged from Communion, and in contrast to the saturated (and serious) reporting in the mainstream press, the Catholic newspapers did not widely cover the event. The Catholic Herald, similarly had run a hostile (and patronising) editorial in January 1964 entitled 'The sad case of Dr Biezanek $^{, 143}$ and on 5 June 1964 proffered a two paragraph factual

139 Ibid. See also 'Woman Doctor Challenges Dr Heenan Today', Sunday Express, 31 May 1964.

140 'Communion Given to Birth Control Doctor', Daily Mail, 1 June 1964, 1. See also 'Dr. Heenan Stays Out of Communion Affair', Daily Mail, 2 June 1964, 7.

141 Daily Mirror, 1 June 1964, p.3

142 Bieżanek, All Things New, 45. Her status as 'everywoman' was, however, a slightly strained construction-highly educated, working in a respected profession with status (all the media reports cited her title), and well connected through her family background, her working-class credentials were based on her region and standard of living.

143 'The Sad Case of Dr Biezanek', Catholic Herald, 17 January 1964, 4 and her response (published in the Letters to the Editor), Catholic Herald, 24 January 1964, 2. 
piece under the banner 'Dr Biezanek at Westminster'. ${ }^{144}$ Meanwhile the more middle class, intellectual Tablet extraordinarily did not report on any of these happenings over six months, but ran theologically dense commentaries on the ambiguities of Church teaching ${ }^{145}$ while merely carrying an advertisement for the book. ${ }^{146}$ The Catholic Herald similarly tended to call upon CMAC doctors and educationalists such as Jack Dominion and Rosemary Haughton to write opinion pieces, ${ }^{147}$ which they hoped would inform the impassioned and highly charged discussions of Catholics' dilemmas in their correspondence columns. ${ }^{148}$ In contrast, The Universe dodged discussion of the issue almost entirely - a stance endorsed by one correspondent (on behalf of Catholic parents) as this 'delicate subject ... is not suitable [for ventilation] in the columns of the most popular Catholic family newspaper., ${ }^{149}$ Dr Bieżanek's media persona must therefore be placed in the broader context of a fascination within the secular press with radical and progressive claims of a 'Church in crisis. ${ }^{150}$ As Sam Brewitt-Taylor has recently explored when analysing commentary on the Church of England, rhetorics of religious disintegration and sexual modernisation were not so much 'discovered as invented' in the early 1960s and Christians played a crucial role in the construction of this moral revolution. ${ }^{151}$ There was, of course, also a sensationalist, gendered and anti-Catholic dimension to some of the reporting - a sense through most of the articles that the medieval mentality

144 'Dr Biezanek at Westminster', Catholic Herald, 5 June 1964, 1.

145 Maurice O'Leary, 'The Pill: The Church's Teaching on Contraception', Tablet, 25 April 1964, 481; 'Femina', 'What Women think about the Pill', Tablet, 23 May 1964, 586-7; P. H. G. Tak, 'The Contraceptive Pill: A Summary of Recent Theological Discussion', Tablet, 2 May 1964, 489-91.

146 'Catholics and Contraception, The Book that Cannot be Ignored. Dr Anne Biezanek's All Things New. Convert, Doctor, Mother of Seven', Tablet, 6 February 1965, 155.

147 E.g. Dr J. Dominian, 'Summary of the Birth Control Debate', Catholic Herald, 22 May 1964, 4 and Rosemary Haughton, 'Family Planning - its Quality not Quantity that Counts', Catholic Herald, 5 June 1964, 7. Rosemary Haughton contributed an important chapter on 'Birth Control and the Ideals of Marital Sexuality', in Contraception and Holiness: The Catholic Predicament (London: Collins, 1965), 65-80. For further information on both of these Catholic laypeople, see Jack Dominion, Being Jack Dominion-Reflections Marriage, Sex and Love (London: SPCK, 2007) and Eilish Ryan, Rosemary Haughton: Witness to Hope (Kansas City: Sheed and Ward, 1997).

148 E.g. Letters to the Editor: 'Problems of Birth Control Doctrine', Catholic Herald, 22 May 1964, 5; 'Birth Control: Some Mothers Hit Back', Catholic Herald, 29 May 1964, 5 and 'More Questions on the "Pill"', Catholic Herald, 12 June 1964, 5.

149 A Keohane, 'The Pill', The Universe, 26 June 1964, 3

150 See, for example, the explicit linkage made between Dr Bieżanek and Dr John Rock, e.g. 'Bishops Bans Woman Birth Control Doctor', Daily Mail, 9 January 1964, 1 and Anne Scott-James' column which claimed 'Religious controversy has not raged so strongly in England since the Tractarians and the Oxford Movement', Daily Mail, 30 April 1964, 10. ${ }_{151}$ Sam Brewitt-Taylor, 'The Invention of a "Secular Society"? Christianity and the Sudden Appearance of Secularizaton Discourses in the British National Media, 1961-4', Twentieth Century British History 24, 3(2013): 330-1. On the nature of the 'sexual revolution' as a construct, see Weeks, The World We Have Won: The Remaking of Erotic and Intimate Life (London: Routledge, 2007); Dominic Sandbrook, White Heat: A History of Britain in the Swinging Sixties (London, 2006) and Nigel Yates, Love Now, Pay Later? Sex and Religion in the Fities and Sixties (London, SPCK, 2010). 
of Rome was being exposed ${ }^{152}$ yet also a fascination with Dr Bieżanek and her candour, confidence and intractability which, as a commentator and former school colleague writing for the Family Planning magazine admitted, could be off-putting as it suggested her revelling in publicity. ${ }^{153}$

Recalling these events herself from the distance of a lifetime, Dr Bieżanek felt shocked at her own audacity and summarized her early interventions in the birth control debate as the equivalent of the 'little boy who'd shouted "the emperor has no clothes on", you know, that's really what happened. ${ }^{154}$ Dr Bieżanek's refrain would be taken up in earnest, and monumentally amplified, four years later when many laymen and women, alongside some clergy, petitioned Rome and commandeered the media to voice their own disillusionment with the disjuncture between dogmatic teaching and ordinary, married practice. While her own cause célèbre was, as she admitted, a 'nine day wonder', ${ }^{155}$ these confrontations in the press and the politicisation of the sacraments anticipated further confrontations in Churches across the countrywranglings in the confessional and a deluge of angry correspondence in letters' pages following the leaked Majority Report and Paul VI's encyclical.

\section{Conclusion}

In the opening pages to All Things New, Dr Bieżanek reflected on the public reaction to her clinic (and her highly-reported confrontation with the English Catholic Church) and rhetorically asked: 'What is it that has prompted so many people to write to me, and to write in such moving and intimate terms, to me, a stranger? ${ }^{256}$ As an answer to this question in the pages that followed, she conjectured that it was 'a revelation of a state of affairs that has always prevailed but has hitherto been nicely walled up behind the respectable façade of "Christian marriage". ${ }^{157}$ In the letters reprinted, which themselves warrant an

\footnotetext{
152 These elements of a 'shrill' opposition to the Church and 'anti-Catholic bigotry' are acknowledged by Monica Furlong, 'But Look Behind Dr Biezanek's Heartbreak Problem', Daily Mail, 22 January 1964, 8.

${ }_{153}$ Sheila Seyd, 'Dr Anne Biezanek', Family Planning, April 1964, 18-20.

154 Interview, 3.

155 Ibid, 13.

156 Bieżanek, All Things New, 13. The exact number of letters received by Dr Bieżanek is unknown (if contrasted with the 4000 or so received by Bishop John Robinson in the wake of Honest to God), but it is likely to have been several thousand. When asked about the number she replied: 'Hundreds! I kept them for a while, but I mean after several years there was [sic] just sacksful of them... The postman used to have to do a special delivery. They would write to just "The Birth Control Clinic, Liverpool". That used to find me, from different parts of the world, amazing.' Interview, 13. 34. Her daughter, Victoria Campbell, remembers that her mother had overwhelming support locally and across the world, with 'enormous kit bags full of mail that the postman used to deliver daily over a long period of time.' (Personal email communication with Victoria Campbell, 24 June 2015). Unfortunately, a large quantity of letters were discarded in a family purge some years ago, so all that survives are the selected and anonymous extracts from early correspondence reprinted in the Appendix to All Things New.

${ }_{157}$ Ibid, 69.
} 
extended analysis, the voices of ordinary Catholics and, in particular, women who recounted the terrors of sex without contraception and the strains of multiple births are accessible, overcoming reticence and embarrassment. Congratulatory, colloquial, and often confessional, their tenor is exemplified in extracts such as: 'you have made public a problem which has haunted women secretly for many a long year ${ }^{158}$ or 'we use contraceptives and so do all my Catholic friends. ${ }^{159}$ Reminding the historian of sexuality of the letters penned by exhausted mothers and anguished husbands to another British sex reformer, ${ }^{160}$ in the course of our conversations in Wallasey I asked Dr Bieżanek whether she had read Marie Stopes' Married Love (1918), to which she responded 'Yes, I did become, yeah, very impressed with it, very impressed with what they did. ${ }^{, 161}$ The distance travelled by British society and the English Catholic Church since Marie Stopes first set up her clinic in north London in 1921 and, technically, lost her libel suit against the Roman Catholic convert and medical practitioner, Dr Halliday Sutherland, is palpable. ${ }^{162}$ Yet there are some surprising, counter-intuitive parallels which may be drawn, if All Things New is compared to Stopes' A New Gospel to All Peoples - the latter inspired by a 'prophetic dream' in her garden in Leatherhead and delivered to the Anglican bishops at Lambeth in 1920 to persuade them of the divine sanction given to birth control. ${ }^{163}$ Similarly, more comparisons emerge if viewed through the lens of the media and its capricious constructions of 'femininity', 'professional status' and 'moral respectability' projected onto the body of the female sex (or Church) reformer ${ }^{164}$-including the newspapers' fixation with the fashion sense and copious auburn hair of Dr Stopes and Dr Bieżanek alike. ${ }^{165}$

\footnotetext{
158 Ibid, 156

159 Ibid, 157

160 See Deborah Cohen, 'Private Lives in Public Spaces: Marie Stopes, the Mothers' Clinic and the Practice of Contraception', History Workshop Journal 35 (1993): 96-116; Claire Davey, 'Birth Control in Britain during the Interwar Years: Evidence from the Stopes Correspondence' Journal of Family History 13, 3(1988): 329-345; Ruth Hall, ed, Dear Dr. Stopes: Sex in the 1920s (Harmondsworth: Penguin, 1981); Leslie Hall, Hidden Anxieties: Male Sexuality, 1900-1950 (Cambridge: Polity, 1991); Alexander C. T. Geppert, 'Divine Sex, Happy Marriage, Regenerated Nation: Marie Stopes' Marital Manual Married Love and the Making of a Best Seller, 1918-1955', Journal of Sexuality 8, 3 (1998): 389-433.

161 Interview, 34.

162 See Muriel Box (ed.), The Trial of Marie Stopes (London: Femina, 1967). On the shifting perspectives of Catholic doctors broadly in this period, see 'Doctors Clash on Birth Control Pill', Daily Mail, 8 May 1964, 1.

163 Marie Carmichael Stopes, A New Gospel to All Peoples (London: Arthur L. Humphries, 1922).

164 For an exploration of a similar fixation with Maude Royden's appearance, see Sue Morgan, 'A "Feminist Conspiracy": Maude Royden, Women's Ministry and the British Press, 1916-1921’, Women's History Review 22, 5 (2013): 777-800, 788.

165 Lesley A. Hall, 'Marie Charlotte Carmichael Stopes (1880-1958)' in Oxford Dictionary of National Biography, eds. Brian Harrison and Lawrence Goldman (Oxford: Oxford University Press, 2004).
} 
While it may tempting to view Dr Anne Bieżanek as a 'Catholic Marie Stopes', particularly in her fearless conviction and singleminded courage in tackling moral certitudes, Dr Bieżanek's explicitly Catholic clinic in 1960s Wallasey dispensed the pill to her married co-religionists and ministered to a very different social and sexual landscape, including more developed cultures of sexual knowledge, ${ }^{166}$ the near-contemporaneous establishment of the Brook Advisory Centre, the promotion of the 'safe period' through the Catholic Marriage Advisory Council, ${ }^{167}$ and the longstanding infrastructure of the Family Planning movement. As Stephen Brooke has argued, 'in the midst of the "secularization" of Britain, the Churches themselves became agents of permissiveness ${ }^{168}$ and the media clearly was another key player in conjuring and then sustaining a crisis of religion. Whether authored by John Robinson or Anne B-, newspapers conveyed a conviction of sexual modernity in the making. ${ }^{169}$ This changed backdrop should also include a Church undertaking its own, perhaps belated, dialogue with a highly particularized construction of the 'modern world' - an aggiornamento that would have consequences for the ways in which discourses and experiences of authority and the 'primacy of conscience' were refashioned in the years following the Second Vatican Council. And yet, the temptation to make comparisons with other British radicals and utopian sex reformers across the century remains. Recalling the support of local Liverpudlians when she again hit the headlines in 1993 - this time for supplying cannabis (for therapeutic purposes) to her youngest, mentally ill daughter ${ }^{170}$ - Dr Bieżanek's son recounted that 'people would ask how... mum was bearing up, and say "well, you know, we've always loved your mum ever since she gave the Pope a bloody nose!" ${ }^{171}$ So perhaps it is not a far stretch to situate Dr Bieżanek in a genealogy of those she celebrated in All Things New - single-minded, farsighted and slightly solipsistic mavericks on the fringe who sought to improve 'women's lot' through female emancipation, the right to enter the professions, to own property and to exercise the vote. ${ }^{172}$ Other querulous women, and some men too, who diagnosed the 'birth pangs' of a new social and spiritual order and were motivated by idealism but accused of iconoclasm.

\footnotetext{
166 See Simon Szreter and Kate Fisher, Sex Before the Sexual Revolution: Intimate Life in England, 1918-1963 (Cambridge: Cambridge University Press, 2010), 364-383.

167 Harris, 'Love Divine and Love Sublime', 211-4 and Harris, Faith in the Family, 106-7, 163 .

168 Brooke, Sexual Politics, 177.

169 Brewitt-Taylor, 'The Invention of a "Secular Society"?', 328.

170 See Lydia Slater, 'Is Medicine Going to Pot?', Daily Mail, 9 August 1994, 42-3.

171 Interview, 5.

172 Bieżanek, All Things New, 72.
} 